\title{
JULIO ÁNGEL OLIVARES MERINO
}

\author{
Pendulum \\ The Grove 6 (1999)
}

Tarns in chiaroscuro, sloth and riddles the wind facing West chanteth.

Aligned aureoles of blissful mortuary

dissonance,

lengthened shroud of forgotten hysteria,

the cry of armless and blind cherubs, for rapture

of senses longing,

Thy chest will behold.

Swamps of a soul's reflection, the dance of a pendulum.

The masquerader thine own tears wept,

The angel and the siren in a romance, portraying skies.

Timeless eruption of silhouettes, from the bulk of dead...sightveilers at dusk...

Nine sighs from the enchanted weeds.

Where all beauty lies, leaning on destiny,

No blemish of sonority in the thicket of desolation,

A crescent of howlings, a pounding, so distant

for thy tragic immensity...

Thou will find just solitude...

Trace the bracelet, my sweetest murmur, my

Crypt Dancer...

And with a mourning eye at the depth of rhyme, poetry and ribbons of melancholy, all in the wasteland of evenfalls,

thou will remain...in perfidity swollen.

To these words no tongue thou will behold, enameled and embalmed by the calling inside, a mistress in the shade...

Stoical oaths vanish as I remember the last dusk in thy shrine...

Wintry waters and one weaken drop of musk, Is all that now echoes this unscriptured nowhere. 


\section{Forlorn Cerements of a Rebirth}

The craved mask in graven odes upon thy shore lieth...

...Upon thy haunted dreams feedeth, Symphonia, my deceased December.

A crimson veiled thorn, so-called winter, amdist the marbled angels danceth...

...Over graves of velvet and stigmata, under the protruding skies of nemesis...

A fainting embrace, languid flame of a whisper, a remembrance within.

Auroral macabre chiming, and the wolf fadeth...no shade...

Thou, night, partaking of the plenilunia, chorus animae...

The winged-Faustus-in-me for my wasted splendour blameth.

Wept vigil, for thee a ribboned oppressive wish in fathomless serenity.

Eden purged by the enchantress that ebony feareth, thou sense me...

And waters of sigils, the shroud of timelessness webs.

Tears of lamentia, a ritual of seduced lucidity... As thou mourn me... 


\section{A Tale of Bliss}

The Grove 25 (2018-2020)

I feel alive, born in flames

You wonder why,

I've returned

Read the lights all over the garden's stage

Sense I am back,

Clouds inside

The universe preserved my path

Bound to blast out in your withered time

Come and shine...

I am calling you.

\section{CHORUS:}

Faith... you know the years

Tearing us apart

A thorn of fears

But now here's my love

Draining lakes

Over you...

And I'll stay

"struggling..."
Be the light

So that my blood runs wild

Catch the moon...

Bring back the falling stars...

Let my heart ...

\section{CHORUS:}

Bathe the pale...

It lasts forever.

We're breaking through

The walls of never

Sailing plains

Chasing winds

The lamps are full...

Drain all the lakes

Stand by me and taste

I am growing pure

Within your cure

It's coming true.

A blissful lie...

"I'll rest in peace"

(To listen to the song, click on the following link:

https://www.youtube.com/watch?v=NPM-rw9cfo8) 
Julio Ángel Olivares Merino (BA, Granada 1992; PhD, Jaén 1999) teaches English Literature at the University of Jaén, Spain. His research revolves arond Gothic fiction and film, semiotics and narratology relating to music, film, literature and popular culture. Managing Director at UniRadio Jaén, the academic radio station at the University of Jaén, his studies also focus on creativity in the classroom, mainly dealing with the use of radio, its registers and didactic resources, in teaching. His books include, among others, The Ring: una mirada al abismo (2005), an approach to Nakata's J-Horror masterpiece, as well as a study of Spanish director Jaume Balagueró (En nombre de la oscuridad, 2001).

$\mathrm{He}$ is also a fiction writer -with more than 15 published novels, La piel leve (2020) being his last release-, as well as an actor and artistic director of a theatre Company (Delirium. Laboratorio de Artes Escénicas).

Composed and written by Julio Ángel Olivares Merino (vocals and guitars in Witchshire) "A Tale of Bliss", a ballad deconstructing the foundations of love songs, was recorded in 2018, more than two decades after the band had splitted up. It is part of a double album under the title Phantasmagoria (2020), including twenty-five previously unrealeased tracks which illustrate Witchshire's holistic and open-minded approach to the metal genre, based on literary references and philosophical views, pushing forward the limits and conventions of hard rock, back in the 90's. 